\title{
The Residual Effect of the Modified White CKD on Peas Plants Grown in Sandy Soil
}

\section{MA Morsy*, GM El-Dawwy, HA Hassan and KH Mohammed}

Soil Science Department, Faculty of Agriculture, Minia University, Egypt

*Corresponding Author: MA Morsy, Soil Science Department, Faculty of Agriculture, Minia University, Egypt.

Received: March 25, 2019; Published: June 18, 2019

DOI: 10.31080/ASAG.2019.03.0531

\begin{abstract}
The reuse of cement kiln dust (one of the by-products of cement industry) prevents or at least reduces the environmental pollution. The CKD is beneficial as a raw material, construction material, absorbent, and improving the sandy soil properties. Pot experiment was carried out in Soil Sci. Dept., Faculty of Agric., Minia Univ., El-Minia, Egypt to study the residual effect of fine CKD on the second crop (peas) grown in the same pots, that were previously treated with CKD at rates $0,2,4,6$, 8, and $10 \mathrm{~g} \mathrm{~kg}^{-1}$ and used for the first crop (corn). In this experiment, peas seeds were planted in each pot. In general, treating the sandy soil with the different application rates of fine CKD increased the vegetative growth parameters (plant height, fresh and dry weights), water use efficiency and uptake of $\mathrm{N}, \mathrm{P}$, and $\mathrm{K}$ by peas plants grown in the treated sandy soil, compared with the untreated control. The increase in almost the studied parameters, was proportional to the increase in the application rate of CKD up to $8 \mathrm{~g} \mathrm{~kg}^{-1}$. It could be concluded that it is possible using the white CKD at application rate of $8 \mathrm{~g} \mathrm{~kg}^{-1}$ as a soil amendment for sandy soils in Egypt. Also, it is possible to use CKD only once for its initial and residual effects on the successive crops grown in the newly reclaimed sandy soils in El-Minia Governorate, Egypt.
\end{abstract}

Keywords: Sandy Soil; CKD and Peas

\section{Introduction}

The cultivation of new area of sandy and sandy calcareous soils represents a necessity to increase food production in Egypt. Large quantities of CKD are produced during the manufacture of cement clinker by the dry process. Fine particles of CKD contain higher concentration of sulfate and alkalies, which cause undesirable environmental impacts.

Over the past several years dramatic advances have been achieved in the management and use of cement kiln dust, thus reducing its dependency on landfill disposal. CKD consists primarily of calcium carbonate and silicon dioxide which is similar to the cement kiln raw feed.

The dust may provide potassium and trace metals that are also depleted from agricultural soils due to plant withdrawal requirements.

Application of the cement kiln dust improves the soil properties so as to provide suitable conditions for the plant growth [1-10].

This study was designed to investigate the residual effect of using the cement kiln dust on
1. Some chemical properties and nutrients availability in the coarse textured soil.

2. Some agronomic aspects of peas plants grown on the coarse textured soil.

\section{Materials and Methods}

- Soil: The soil used in this study was sandy loam in texture and was collected from the newly reclaimed desert land at the Western district of the Nile Valley, West of Samalout, El-Minia Governorate, Egypt. Some analytical data of the studied soil are given in Table 1.

- Cement Kiln Dust (CKD): Cement kiln dust was collected from El-Minia White Cement Factory. A representative sample was taken from CKD, modified and analyzed as raw material and after modification (Table 2).

- Cement kiln dust modification: It is known that the CKD has a high content of salts and soluble ions. Its application to a soil causes salinity build up in the soil. The CKD need to be leached with 20 times water so as to decrease its content of salts and soluble ions. 


\begin{tabular}{|c|c|c|}
\hline \multicolumn{2}{|c|}{ Soil properties } & Value \\
\hline \multirow{4}{*}{$\begin{array}{c}\text { Particle size } \\
\text { distribution: } \\
\qquad \%)\end{array}$} & Coarse sand & 41.80 \\
\hline & Fine sand & 30.08 \\
\hline & Silt & 10.20 \\
\hline & Clay & 17.92 \\
\hline \multicolumn{2}{|c|}{ Texture } & Sandy loam \\
\hline \multicolumn{2}{|c|}{$\mathrm{pH}(1: 2.5)$} & 7.74 \\
\hline \multicolumn{2}{|c|}{$\mathrm{CaCO}_{3}, \mathrm{gkg}^{-1}$} & 128.00 \\
\hline \multicolumn{2}{|c|}{$\mathrm{OM}, \mathrm{gkg}^{-1}$} & 1.50 \\
\hline \multicolumn{2}{|c|}{$\mathrm{EC}, \mathrm{dSm}^{-1}$ (soil paste extract) } & 2.73 \\
\hline \multicolumn{2}{|c|}{ Soluble cations, $\mathrm{mmol} / \mathrm{l}$ : } & \\
\hline \multicolumn{2}{|c|}{$\mathrm{Na}^{+}$} & 3.10 \\
\hline \multicolumn{2}{|c|}{$\mathrm{K}^{+}$} & 1.10 \\
\hline \multicolumn{2}{|c|}{$\mathrm{Ca}^{2+}$} & 1.05 \\
\hline \multicolumn{2}{|c|}{$\mathrm{Mg}^{2+}$} & 0.85 \\
\hline \multicolumn{2}{|c|}{ Soluble anions, $\mathrm{mmol} / \mathrm{l}$ : } & \\
\hline \multicolumn{2}{|c|}{$\mathrm{Cl}^{-}$} & 4.10 \\
\hline \multicolumn{2}{|c|}{$\mathrm{HCO}_{3}^{-}$} & 0.80 \\
\hline \multicolumn{2}{|c|}{$\mathrm{CO}_{3}{ }^{2-}$} & - \\
\hline \multicolumn{2}{|c|}{$\mathrm{SO}_{4}{ }^{2-}$} & 1.05 \\
\hline \multicolumn{2}{|c|}{ Available P, ppm } & 16.00 \\
\hline \multicolumn{2}{|c|}{ Available K, ppm } & 237.90 \\
\hline \multicolumn{2}{|c|}{ Available Fe, ppm } & 2.20 \\
\hline \multicolumn{2}{|c|}{ Available Mn, ppm } & 0.50 \\
\hline \multicolumn{2}{|c|}{ Available Zn, ppm } & 0.30 \\
\hline
\end{tabular}

Table 1: Some analytical data of the studied soil.

\begin{tabular}{|c|c|c|c|c|}
\hline CKD chemical properties & $\begin{array}{c}\text { Unleashed raw } \\
\text { white CKD }\end{array}$ & $\begin{array}{c}\text { leaching with 5 } \\
\text { times water }\end{array}$ & $\begin{array}{c}\text { leaching with } \\
\text { 10 times water }\end{array}$ & $\begin{array}{c}\text { leaching with } \\
\text { 20 times water }\end{array}$ \\
\hline $\left.\mathrm{EC}(\mathrm{dS} \mathrm{m})^{-1}\right)$ & 10.3 & 7.4 & 6.1 & 4.8 \\
\hline $\mathrm{Na}^{+}\left(\mathrm{g} \mathrm{kg}^{-1}\right)$ & 0.3 & 0.2 & 0.1 & 0.1 \\
\hline $\mathrm{K}^{+}\left(\mathrm{g} \mathrm{kg}^{-1}\right)$ & 0.2 & 0.1 & 0.1 & 0.1 \\
\hline $\mathrm{Ca}^{2+}\left(\mathrm{g} \mathrm{kg}^{-1}\right)$ & 9.2 & 5.2 & 4.5 & 4.1 \\
\hline $\mathrm{Mg}^{2+}\left(\mathrm{gkg}^{-1}\right)$ & 0.2 & 0.1 & 0.1 & 0.1 \\
\hline $\mathrm{Cl}^{-}\left(\mathrm{g} \mathrm{kg}^{-1}\right)$ & 2.8 & 0.9 & 0.4 & 0.2 \\
\hline $\mathrm{HCO}_{3}^{-}\left(\mathrm{gkg}^{-1}\right)$ & - & - & - & - \\
\hline $\mathrm{CO}_{3}^{-2}\left(\mathrm{~g} \mathrm{~kg}^{-1}\right)$ & 7.0 & 5.0 & 4.8 & 2.8 \\
\hline $\mathrm{SO}_{4}^{-2}\left(\mathrm{~g} \mathrm{~kg}^{-1}\right)$ & 4.8 & 3.8 & 2.6 & 2.2 \\
\hline
\end{tabular}

Table 2: Effect of the leaching treatments with the tap water on some chemical properties of the white CKD. 
As can be seen from Table 2 that increasing the leaching treatments from 0 times water (unleashed) up to 20 times water gradually decreased the E.C. and soluble ions of CKD compared to those of the unleashed one. The lowest values of $\mathrm{EC}, \mathrm{Ca}^{2+}, \mathrm{Mg}^{2+}, \mathrm{Na}^{+}, \mathrm{K}^{+}$, $\mathrm{Cl}^{-}, \mathrm{SO}_{4}{ }^{2-}$ and $\mathrm{CO}_{3}{ }^{2-}$ were obtained when $\mathrm{CKD}$ was leached with 20 times water. Therefore, the best leaching treatment for the CKD is the leaching with 20 times water. Similar results were obtained by Deaus 2002 and 2007.

In the current study, we decided to use the modified white CKD (leached with 20 times water) in the pot experiment in order to study their effect on the peas plants growth, water use efficiency and nutrients uptake.

Set up of the pot experiment

Pot experiment was carried out in Soil Sci. Dept., Faculty of Agric., Minia Univ., Elminia, Egypt to study the residual effect of fine CKD on the second crop (peas) grown in the same pots, that were previously treated with CKD at rates $0,2,4,6,8$, and $10 \mathrm{~g} \mathrm{~kg}^{-1}$ and used for the first crop (corn), without new addition of CKD. In this experiment, four seeds of peas were planted in each pot. The plants in each pot were thinned and two plants were left to grow in each pot and fertilized with $\mathrm{N}$ and $\mathrm{P}$ at the equivalent rates of $250 \mathrm{~kg} \mathrm{~N}$ and $155 \mathrm{~kg} \mathrm{P}_{2} \mathrm{O}_{5}$. ha- ${ }^{-1}$ The plants were irrigated every ten days with an amount of water to compensate the loss in moisture which was maintained at the field capacity. At 60 days from the peas planting, the plant height $(\mathrm{cm})$ and water consumptive use by the plants $(\mathrm{l} /$ pot) were recorded. The peas plants were cut at $2 \mathrm{~cm}$ from the soil surface and its fresh weight was recorded (g/pot). The fresh materials were dried at $65^{\circ} \mathrm{C}$ and the dry weight (g/pot) was recorded by weighing. Also, the water use efficiency by the peas plants was calculated. The oven dried peas shoots were grinded in a plant mill, passed through a $0.5 \mathrm{~mm}$ screen mesh, and a representative sample was taken and analyzed for the total nitrogen, total phosphorus, and total potassium.

Analyses of soil, CKD, and plant tissues were determined according to the standard methods $[11,12]$.

All recorded data were subjected to statistical analysis of variance procedures. Treatments means were compared using the L.S.D. according to Gomez and Gomez [13].

\section{Results and Discussion}

Results of the residual effect of applying the tested CKD to the sandy soil on some vegetative growth parameters, water use efficiency, concentration and uptake of $\mathrm{N}, \mathrm{P}$, and $\mathrm{K}$ by the second successive crop (peas), are presented in Tables 3 and 4.

\begin{tabular}{|c|c|c|c|c|c|}
\hline \multirow{2}{*}{$\begin{array}{l}\text { CKD treatments } \\
\mathrm{g} \mathrm{kg}^{-1}\end{array}$} & \multirow{2}{*}{$\begin{array}{l}\text { Plant height } \\
\text { (cm) }\end{array}$} & \multirow{2}{*}{$\begin{array}{l}\text { Fresh weight } \\
\text { (g/ pot) }\end{array}$} & \multirow{2}{*}{$\begin{array}{c}\text { Dry } \\
\text { weight }(\mathrm{g} / \text { pot) }\end{array}$} & \multicolumn{2}{|c|}{ Water use } \\
\hline & & & & W.C.U.** (L) & W.U.E.*** $\left(\mathrm{g} \mathrm{L}^{-1}\right)$ \\
\hline Control & 40.17 & 14.17 & 3.20 & 3.11 & 0.97 \\
\hline 2 & 41.83 & 16.97 & 3.63 & 3.18 & 1.14 \\
\hline 4 & 43.83 & 18.50 & 3.70 & 3.16 & 1.17 \\
\hline 6 & 47.33 & 19.67 & 3.73 & 3.11 & 1.20 \\
\hline 8 & 49.00 & 20.50 & 3.83 & 2.99 & 1.28 \\
\hline 10 & 48.17 & 19.63 & 3.70 & 2.84 & 1.30 \\
\hline L.S.D. at $5 \%$ level & 4.18 & 3.92 & 1.03 & - & 0.04 \\
\hline
\end{tabular}

Table 3: The residual Effect of the tested CKD on some vegetative growth parameters and water use by the peas plants.

* Each value in the table is the mean of three replicates.

** W.C.U.: Water consumptive use (L).

***W.U.E.: Water use efficiency $\left(\mathrm{g} \mathrm{L}^{-1}\right)$

\begin{tabular}{|l|c|c|c|c|c|c|}
\hline \multirow{2}{*}{$\begin{array}{c}\text { CKD } \\
\text { treatments } \\
\text { g k-1 }\end{array}$} & \multicolumn{5}{|c|}{ Nutrients concentration and uptake by the peas plants } \\
\cline { 2 - 7 } & \multicolumn{2}{|c|}{$\mathbf{N}$} & \multicolumn{2}{c|}{$\mathbf{c}$} & \multicolumn{2}{c|}{ K } \\
\hline Control & 2.42 & 8.58 & 0.25 & 0.90 & 2.19 & 8.39 \\
\hline 2 & 2.60 & 9.45 & 0.27 & 0.92 & 2.40 & 8.72 \\
\hline 4 & 2.75 & 10.18 & 0.29 & 1.07 & 2.59 & 9.58 \\
\hline 6 & 2.92 & 10.90 & 0.31 & 1.40 & 2.78 & 10.38 \\
\hline 8 & 3.32 & 12.73 & 0.36 & 1.72 & 3.22 & 12.34 \\
\hline 10 & 3.11 & 12.51 & 0.34 & 1.70 & 3.00 & 11.10 \\
\hline $\begin{array}{l}\text { L.S.D at } \\
\text { 5\% level: }\end{array}$ & 1.41 & 1.33 & 0.01 & 0.18 & 1.33 & 1.00 \\
\hline
\end{tabular}

Table 4: The residual effect of the tested CKD on the nutrients concentration and uptake by peas plants.*

*Each value in the table is the mean of three replicates. 
Data given in Table 3 reveal that treating the sandy soil with the different application rates of CKD generally increased the vegetative growth parameters i.e plant height, fresh and dry weights of peas plants grown in the sandy soil, compared with the untreated control. The increase in almost the studied plant growth parameters was proportional to the increase in the application rate of CKD up to $8 \mathrm{~g} \mathrm{~kg}^{-1}$.

The increase in the plant growth parameters, due to the application of CKD, was great and significant.

The improvement in growth parameters of peas plants may be attributed to the effect of CKD on improving soil structure and water regime, as they increased the water available to plants and reduced the evaporation of water from the soil surface. Also, the improvement in growth parameters may be attributed to the content of CKD of elements (Table 2) and that reflected on soil fertility.

As the water use efficiency refer to the amount of dry plant materials produced by unit of water, and as the dry matter yield of the peas shoots grown in the treated soil with CKD was much higher than in the untreated one (Table 3), it could be seen that the water use efficiency was also increased.

The increase in water use efficiency due to treating the sandy soil with CKD could be attributed to the effect of CKD on increasing the water holding capacity of the treated soil and decreasing the water evaporation from the soil surface, hence. It increased the water available to the plants. The available water will be used in producing more plant materials and then more water use efficiency.

Data dealing with the effect of the tested CKD on concentration and uptake of N, P, and $\mathrm{K}$ by the peas plants are presented in Table 4.

Careful examination of the data presented in Table 4 show that the concentration and uptake of all the studied nutrients were increased with treating the sandy soil with CKD up to $8 \mathrm{~g} \mathrm{~kg} \mathrm{-1,} \mathrm{com-}$ pared with the untreated one.

The increase in the nitrogen, phosphors and potassium concentration in the plants was significant $(\mathrm{p}=0.05)$.

The increase in N, P, and K uptake by the peas plants was significant $(\mathrm{p}=0.05)$.

The increase in N, P, and K uptake by the peas plants could be attributed to the increase in dry matter and nutrients concentration in the peas plants.

Generally, the increase in nutrients uptake may be due to one or more of the following reasons:
- The increase in the dry weight of plants grown in the studied soil (Table 3).

- The increase in ion mobility due to the increase in the retained water in the studied soil.

- Increasing C.E.C. of the tested sandy soil because of the clay fraction in the tested CKD.

- The improvement in soil structure which reflected on increasing the water holding capacity and decreasing nutrients losses by leaching and deep percolation.

Similar results were obtained by Hynes and Kramer, 1982, and Lafond and Simard (1999) using CKD. without going in more details, it is preferable to compare the residual effect of the tested CKD on the mean values of growth parameters, water use efficiency and concentration and uptake of $\mathrm{N}, \mathrm{P}$, and $\mathrm{K}$ by the second successive crop (peas), with its initial effect on the first crop (corn).

Since the two tested crops differed in all the above mentioned parameters due to the genetically differences, it is preferable to calculate and compare the mean values of these parameters as effected by the application of CKD to the sandy soil, relative to the untreated control for each crop, as summarized in Tables 5 and 6.

The obtained data given in Tables 5 and 6, make it is possible to conclude the following:

1. The plant height, fresh and dry weights, water use efficiency and concentration and uptake of N, P, and K by peas plants grown in the treated sandy soil were increased, relative to the control due to the residual effect of CKD, while the water consumptive use by peas plants grown in the treated soil were decreased, relative to the untreated one.

2. The relative improvement in almost all the above mentioned parameters by the second successive crop (peas), grown in the treated sandy soil due to the residual effect of the CKD was less than its initial effect on the first crop (corn).

3. The improvement in almost all the studied parameters of the two successive crops due to the initial and residual effects of the tested CKD was obtained from the treatment with $8 \mathrm{~g} \mathrm{~kg}^{-1}$.

The relative improvement in the growth parameters and nutrients uptake by the second crop (peas) grown in the treated sandy soil may be attributed to the residual effect of the CKD on improving the physical, chemical and biological properties of the treated soil, and consequently, on increasing the availability of nutrients in soil and their uptake by the growing plants, compared with the untreated control. 
The Residual Effect of the Modified White CKD on Peas Plants Grown in Sandy Soil

138

\begin{tabular}{|c|c|c|c|c|c|c|c|c|c|c|}
\hline \multirow{2}{*}{$\begin{array}{l}\text { CKD } \\
\text { Treatments } \mathrm{g} \mathrm{k}^{\mathrm{g}-1}\end{array}$} & \multicolumn{2}{|c|}{ Plant height } & \multicolumn{2}{|c|}{ Fresh weight } & \multicolumn{2}{|c|}{ Dry weight } & \multicolumn{2}{|c|}{ Water consumptive use } & \multicolumn{2}{|c|}{ Water use efficiency } \\
\hline & Corn & Peas & Corn & Peas & Corn & Peas & Corn & Peas & Corn & Peas \\
\hline Control & 100 & 100 & 100 & 100 & 100 & 100 & 100 & 100 & 100 & 100 \\
\hline 2 & 109 & 104 & 135 & 119 & 138 & 113 & 96 & 143 & 102 & 117 \\
\hline 4 & 115 & 109 & 144 & 130 & 145 & 115 & 97 & 149 & 101 & 120 \\
\hline 6 & 118 & 117 & 152 & 138 & 151 & 116 & 95 & 159 & 100 & 123 \\
\hline 8 & 124 & 121 & 166 & 144 & 168 & 119 & 95 & 176 & 96 & 131 \\
\hline 10 & 120 & 119 & 155 & 138 & 157 & 115 & 93 & 167 & 91 & 134 \\
\hline
\end{tabular}

Table 5: Effect of the tested CKD application on some vegetative growth parameters and water use by the two successive crops, relative to the control of each crop.

\begin{tabular}{|l|c|c|c|c|c|c|c|c|c|c|c|c|}
\hline \multirow{2}{*}{$\begin{array}{l}\text { CKD } \\
\text { Treat-mens g kg- }\end{array}$} & \multicolumn{4}{|c|}{ N } & \multicolumn{4}{|c|}{ P } & \multicolumn{4}{c|}{ K } \\
\cline { 2 - 13 } & Concentration & \multicolumn{2}{|c|}{ Uptake } & \multicolumn{2}{c|}{ Concentration } & \multicolumn{2}{c|}{ Uptake } & Concentration & \multicolumn{2}{c|}{ Uptake } \\
\cline { 2 - 13 } & corn & peas & corn & peas & corn & peas & corn & peas & corn & peas & corn & peas \\
\hline Control & 100 & 100 & 100 & 100 & 100 & 100 & 100 & 100 & 100 & 100 & 100 & 100 \\
\hline 2 & 108 & 107 & 149 & 103 & 109 & 108 & 149 & 102 & 108 & 109 & 150 & 110 \\
\hline 4 & 116 & 113 & 169 & 114 & 118 & 116 & 171 & 118 & 117 & 118 & 170 & 118 \\
\hline 6 & 130 & 120 & 198 & 123 & 140 & 124 & 208 & 155 & 137 & 126 & 207 & 127 \\
\hline 8 & 140 & 137 & 237 & 147 & 150 & 144 & 247 & 191 & 146 & 147 & 252 & 148 \\
\hline 10 & 123 & 128 & 194 & 132 & 131 & 136 & 200 & 188 & 127 & 136 & 207 & 145 \\
\hline
\end{tabular}

Table 6: Effect of the tested CKD application on concentration and uptake of N, P, and K by the two successive crops, relative to the control of each crop.

Similar results were obtained by Schreiber., et al. (1998), Subha and Dakshinamoorthy [6], Soda., et al. (2006) and Rahman., et al. [9] using CKD [14-16].

\section{Conclusion}

From the obtained results, general conclusions can be made as

Results of the residual effect of applying the tested CKD to the sandy soil on some vegetative growth parameters, water use efficiency, concentration and uptake of $\mathrm{N}, \mathrm{P}$, and $\mathrm{K}$ by the second successive crop (peas), are presented in Tables 3 and 4 .

- It is possible to use CKD only once at a rate of $8 \mathrm{~g} \mathrm{~kg}^{-1}$ for its initial and residual effects on the successive crops grown in the newly reclaimed sandy soils in El-Minia Governorate, Egypt.

- $\quad$ For using the white CKD as an amendment for sandy soils, on a large scale, more studies, probably in field, are still needed. These studies should include the economic aspects of the application of CKD.

\section{Bibliography}

1. Khader S and N Abu-Rub. "The potential use of cement dust as a fertilizer". Dirasat 13.5(1986): 51-60.

2. Fraiman L S., et al. "Study of Properties of Bypass Dust". Tsement, Leningrad, USSR (1991): 9-12.

3. El-Awady MH and TM Sami. "Removal of heavy metals by cement kiln dust". Bulliten of Environmental Contamination and Toxicology 59.4 (1997): 603-610.

4. Lafond J and RR Simard. "Effect of cement kiln dust on soil and potato crop quality". American Journal of Potato Research 76.3 (1999): 83-90.

5. Christie P., et al. "Agronomic value of alkaline-stabilized sewage biosolids for spring barley". Journal of Agronomy 93.1 (2001): 144-151. 
6. Subha SJ and M Dakshinamoorthy. "Effect of cement kiln dust on sorghum and blackgram crops". Agriculture 87 (2001): 444446.

7. Croker J., et al. "Effects of recycled bentonite addition on soil properties, plant growth and nutrient uptake in a tropical sandy soil". Plant and Soil 267.1-2 (2004): 155-163.

8. Adaska WS. "Beneficial uses of cement kiln dust". IEEE/PCA 50th Cement Industry Technical Conf., Miami, FL (2008): 1922.

9. Rahman MK., et al. "Literature review on cement kiln dust usage in soil and waste stabilization and experimental investigation". International Journal of Research and Reviews in Applied Sciences 7 (2011).

10. Morsy M A., et al. "Evaluation of Cement Kiln Dust (CKD) as an Amendment for the Sandy Soils". 1- Preliminary Studies. Egyptian Journal of Soil Science 53.3 (2013): 335-346.

11. Piper CS. "Soil and plant Analysis". Inter Science publisher New York (1950): 42-110.

12. Page A L., et al. "Methods of soil analysis. Part 2: Chemical and biological properties". Agronomy 9, $2^{\text {nd }}$ edition, American Society of Agronomy Madison, Wisconsin, USA. (1982).

13. Gomez KA and AA Gomez. "Statistical procedures in Agricultural Research, New York, chichester: Wiley $2^{\text {nd }}$ edition, paperback 680 (1984).

14. Houba VJG., et al. "Methods of analysis for soils". II. Soil analysis, 1974, Wageningen, The Netherlands (1974).

15. Pankov M A. "Land reclamation". TUUMCX publisher, Tashkent, USSR. (1974).

16. Sing RA. Soil Physical Analysis. Kalyani Publishers, New DelhiLudniana Sehgal, J.L., Sohanlal, and R.M. pofalii. 1992. Sandy soils of India." Agropedology 2 (1980): 1-16.

Volume 3 Issue 7 July 2019

(C) All rights are reserved by MA Morsy., et al. 